\title{
PRODUCTION OF MILK AND MILK COM- PONENTS BY COWS GRAZING DIFFERENT RYEGRASS CULTIVARS
}

I. M. BROOKES

\author{
Dairy Husbandry Department, M assey University
}

J. A. LANCASHIRE

Grasslands Division, DSIR, Palmerston N orth

Abstract

The production of milk and milk components by identical twin cows given ad libitum access to swards of Nui or Ruanui perennial ryegrasses, or a tetraploid hybrid ryegrass (G4708), for short-term periods in spring, summer, and autumn, showed no consistent differences. Similar trials conducted in the spring with unrelated cows grazing Tama tetraploid Westerworlds ryegrass or a tetraploid Italian ryegrass (G4709) also showed no production differences.

The use of these cultivars in dairy production systems is therefore more likely to be determined by such agronomic features as annual and seasonal yields, disease resistance and persistency rather than nutritional characteristics.

\section{INTRODUCTION}

BECAUSE of the importance of animal production from pasture in New Zealand, information on the production characteristics of animals grazing new pasture cultivars is required before their large-scale release to the farming industry. Although information gained from indoor feeding trials and laboratory analyses can be useful, these techniques are not completely satisfactory compared with measurements made using the grazing animal (Lancashire and Harris, 1978).

Previous studies using sheep (Ulyatt, 1970) and dairy cows (Wilson, 1967) have shown that shorter-lived ryegrasses, e.g., 'Grasslands Manawa' (Lolium (multiflorum x perenne) ), when grazed to appetite, produced higher liveweight gains and milk yields, respectively, than perennial types, e.g., 'Grasslands Ariki' (Lolium (multiflorum x perennc) $\mathbf{x}$ pcrenne), and 'Grasslands Ruanui' (Lolium perenne L.) . Differences have also been observed by Wilson and Dolby (1967) in the composition of milk produced by cows grazing 'Grasslands Tama' tetraploid Westerworlds rvegrass (Lolium multiflorum Lam.) and 'Grasslands Paroa' diploid Italian ryegrass (Lolium multiflorum Lam.). 
Two series of grazing trials are described in which comparisons of milk production by cows grazing different perennial or annual ryegrass cultivars were made. The first comparison was between 'Grasslands Nui' (Lolium perenne L.) (a recently released perennial ryegrass - Armstrong, 1977), 'Grasslands 4708' (an experimental tetraploid hybrid ryegrass derived from Ariki, but similar in growth characteristics and animal acceptability to Manawa), and Ruanui (an established perennial ryegrass). The second comparison was between two annual ryegrasses - Tama, and 'Grasslands 4709' (a tetraploid Italian ryegrass derived from the diploid Paroa). G4709 generally has outyielded Paroa, and resembles Tama in growth habit, dry matter content and appearance, but is more persistent.

\section{EXPERIMENTAL}

\section{PERENNIAL RyEgRASS COMPARISONS}

A series of grazing trials were conducted at Massey University No. 3 Dairy from 1977 to 1979 in which identical twin cows grazed pure swards of either Nui, Ruanui or G4708 ryegrasses. The trials were conducted in the springs of 1977 and 1978 and in the summer and autumn of 1979. Dry weather in 1978 prevented summer and autumn comparisons being made in that year.

Approximately 1.7 ha was sown in each ryegrass cultivar, and 12 sets of identical twin cows of mixed breeding were allocated so that each treatment group contained 8 cows with twin mates equally distributed among the other two treatments. All cows calved in the spring and grazed together on mixed ryegrass/ white clover pastures until required for the grazing trials. The cultivars were then grazed for periods ranging from 12 to 18 days. The design of the individual trials is shown in Table 1.

Intakes of pasture by the cows were not measured but were judged to be ad libitum, as estimated by the residue after grazing.

\section{Measurements.}

Daily milk samples were collected and yield recorded for individual cows during both the preliminary period, when the cows grazed mixed pasture, and the experimental period. The length of these periods and number of samples collected are shown in Table 1.

Milk fat contents of the samples were determined using a Foss "Milko Tester", and milk protein contents using a "Pro-Milk" recorder. 
TABLE 1: DESJGN OF GRAZING TRIAIS TO COMPARE THREE PERENNIAL RYEGRASS CULTIVARS (NUI, RUANUI AND G4708)

\begin{tabular}{|c|c|c|c|c|}
\hline & $\begin{array}{c}\text { Spring } \\
1977\end{array}$ & $\begin{array}{c}\text { Spring } \\
1978\end{array}$ & $\begin{array}{c}\text { Summer } \\
1979\end{array}$ & $\begin{array}{c}\text { Autumn } \\
1979\end{array}$ \\
\hline No. of couper treatment & 8 & $a$ & 8 & 8 \\
\hline $\begin{array}{l}\text { Average age of cows at } \\
\text { calving (years)' }\end{array}$ & $4.7 \pm 1.1$ & $4.1 \pm 2.5$ & $3.5 \pm 1.7$ & $3.2 \pm 1.2$ \\
\hline $\begin{array}{l}\text { No. of days in milk" } \\
\text { Length of preliminary }\end{array}$ & & $84 \pm 11$ & & $235 \pm 15$ \\
\hline $\begin{array}{l}\text { period (days)" } \\
\text { Length of experimental }\end{array}$ & $14(8)$ & $14(7)$ & 7 (4) & 7 (4) \\
\hline period (day & $18(11)$ & $12(8)$ & $12(8)$ & $12(8)$ \\
\hline
\end{tabular}

'Mean \pm standard deviation.

${ }^{b}$ Figures in parentheses indicate number of daily milk samples taken.

Samples of each ryegrass cultivar were taken prior to grazing and the digestible organic matter content determined by the in vitro procedure of Tilley and Terry ( 1963).

\section{Statistics}

Treatment differences in mean yield and composition of milk of cows grazing the three cultivars were analysed by covariance analysis, using the preliminary period data as independent variates (Snedecor and Cochran, 1967).

\section{Annual Ryegrass Comparisons}

Two grazing trials were conducted at Massey University No. 1 Dairy in the springs of 1977 and 1978 in which unrelated cows grazed pure swards of either Tama or G4709 ryegrass.

Approximately 0.9 ha was sown in each ryegrass cultivar in 1977, and 0.7 ha in 1978. Twelve unrelated Friesian and Friesian cross cows were allocated to two treatment groups, each 'containing six cows. All cows calved in the autumn and had grazed

TABLE 2: DESIGN OF GRAZING TRIALS TO COMPARE TWO ANNUAL RYEGRASS CULTIVARS (TAMA AND G4709)

\begin{tabular}{lcc}
\hline & Spring 1977 & Spring 1978 \\
\hline No. of cows per treatment & 6 & 6 \\
Average age of cows at calving (years)' & $4.3 \pm 1.1$ & $3.8 \pm 2.2$ \\
No. of days in milk' & $235 \pm 43$ & $251 \pm 37$ \\
Length of preliminary period (days) $^{\text {b }}$ & $5(4)$ & $5(4)$ \\
Length of experimental period (clays) $^{\text {b }}$ & $8(5)$ & $9(6)$
\end{tabular}

Mean \pm standard deviation.

${ }^{b}$ Figures in parentheses indicate number of daily milk samples taken. 
together on mixed pasture prior to the grazing trials. The design of each trial is shown in Table 2.

The grazing management, sampling and statistical analyses were similar to those described for the perennial ryegrass comparisons.

\section{RESULTS}

\section{Perennial Ryegrass Comparisons}

The adjusted mean yields of milk, milk fat and milk prorem and the milk fat and protein contents of cows grazing Nui, Ruanui and G4708 ryegrasses are shown in Table 3.

No -consistent differences were observed, although in autumn 1979, cows grazing G4708 showed an apparent increase in milk

TABLE 3: THE EFFECT OF THREE PERENNIAL RYEGRASS CULTIVARS UPON THE ADJUSTED MEAN YIELDS OF MILK, MILK COMPONENTS AND MILK COMPOSITION

\begin{tabular}{|c|c|c|c|c|c|}
\hline & $\begin{array}{l}N u i \\
(N)\end{array}$ & $\begin{array}{c}\text { Ruanui } \\
(R)\end{array}$ & $\begin{array}{c}G 4708 \\
(G)\end{array}$ & $\begin{array}{l}\text { S.E. of } \\
\text { Means }\end{array}$ & $\begin{array}{l}\text { Sig. of } \\
\text { Diff. }\end{array}$ \\
\hline \multicolumn{6}{|c|}{ Milk yield (litres/day) } \\
\hline Spring 1977 & 13.39 & 13.55 & 12.90 & 0.51 & n.s. \\
\hline Spring 1978 & 13.81 & 13.88 & 13.51 & 0.18 & n.s. \\
\hline Summer 1979 & 10.17 & 10.15 & 10.31 & 0.22 & n.s. \\
\hline Autumn 1979 & 7.75 & 7.95 & 7.79 & 0.24 & n.s. \\
\hline \multicolumn{6}{|c|}{ Milk fat content $(\%)$} \\
\hline Spring' 1977 & 4.91 & 4.77 & 5.07 & 0.10 & n.s. \\
\hline Spring 1978 & 4.61 & 4.72 & 4.67 & 0.06 & n.s. \\
\hline Summer 1979 & 4.71 & 4.67 & 4.67 & 0.05 & n.s. \\
\hline Autumn 1979 & 5.57 & 5.45 & 5.71 & 0.08 & $\mathbf{G}>\mathbf{R}^{*}$ \\
\hline \multicolumn{6}{|c|}{ Milk fat yield (kg/day) } \\
\hline Spring 1977 & 0.65 & 0.63 & 0.65 & 0.02 & n.s. \\
\hline Spring 1978 & 0.64 & 0.65 & 0.63 & 0.01 & n.s. \\
\hline Summer 1979 & 0.47 & 0.47 & 0.47 & 0.01 & n.s. \\
\hline Autumn 1979 & 0.41 & 0.42 & 0.42 & 0.01 & n.s. \\
\hline \multicolumn{6}{|c|}{ Milk protein content $(\%)$} \\
\hline Spring 1977 & 3.84 & 3.83 & 3.90 & 0.03 & n.s. \\
\hline Spring 1978 & 3.62 & $3.69^{\prime}$ & 3.64 & 0.05 & n.s. \\
\hline Summer 1979 & 3.64 & 3.61 & 3.64 & 0.03 & n.s. \\
\hline Autumn 1979 & 4.06 & 3.97 & 4.09 & 0.03 & $\mathrm{G}>\mathrm{R}^{*}$ \\
\hline \multicolumn{6}{|c|}{ Milk protein yield $(\mathrm{kg} /$ day $)$} \\
\hline Spring 1977 & 0.51 & 0.51 & 0.50 & 0.02 & n.s. \\
\hline Spring 1978 & 0.50 & 0.51 & 0.49 & 0.01 & $\mathrm{R}>\mathrm{G}^{*}$ \\
\hline Summer 1979 & 0.36 & 0.36 & 0.37 & 0.01 & n.s. \\
\hline Autumn 1979 & 0.31 & 0.31 & 0.31 & 0.01 & n.s. \\
\hline
\end{tabular}

$* P<0.05$; n.s. $P>0.05$. 
fat and protein contents compared with those grazing Ruanui. In spring 1978, cows grazing Ruanui appeared to yield more milk protein than those grazing G4708.

The organic matter digestibilities of the ryegrass cultivars in each trial are shown in Table 4.

TABLE 4: MEAN IN VITRO ORGANIC MATTER DIGESTIBILITIES OF THREE PERENNIAL RYEGRASS CULTIVARS

\begin{tabular}{|c|c|c|c|c|c|}
\hline \multicolumn{6}{|c|}{ In vitro $D O M D^{*}$} \\
\hline & $\mathrm{N}$ ui & Ruanui & G4 7:08 & $\begin{array}{l}\text { S.E. of } \\
\text { Means }\end{array}$ & $\begin{array}{c}\text { Sig. of } \\
\text { Diff. }\end{array}$ \\
\hline Spring 1977 & 72.1 & 70.1 & 76.3 & 2.27 & n.s. \\
\hline Spring 1978 & $=73.7$ & 72.7 & 71.1 & 2.43 & n.s. \\
\hline Summer 1979 & 60.4 & 60.4 & 60.3 & 1.10 & n.s. \\
\hline Autumn 1979 & 65.2 & 66.1 & 63.9 & 1.20 & n.s. \\
\hline
\end{tabular}

* Digestible organic matter as percentage of dry matter.

n.s. $\mathrm{P}>0.05$.

\section{Annual Ryegrass Comparisons}

The adjusted mean yields and composition of milk from cows grazing Tama and G4709 ryegrasses are shown in Table 5.

TABLE 5: THE EFFECT OF TWO ANNUAL RYEGRASS CULTIVARS UPON THE ADJUSTED MEAN YIELDS OF MILK, MILK COMPONENTS AND MILK COMPOSITION

\begin{tabular}{|c|c|c|c|c|}
\hline & Tama & $G 4709$ & $\begin{array}{l}S . E . \text { of } \\
\text { M eans }\end{array}$ & $\begin{array}{l}\text { Sig. of } \\
\text { Diff. }\end{array}$ \\
\hline \multicolumn{5}{|c|}{ Milk yield (litres/day) } \\
\hline Spring 1977 & 14.22 & 14.08 & 0.63 & n.s. \\
\hline Spring 1978 & 10.79 & 10.60 & 0.32 & n.s. \\
\hline \multicolumn{5}{|c|}{ Milk fat content $(\%)$} \\
\hline Spring 1977 & 4.90 & 4.91 & 0.04 & n.s. \\
\hline Spring 1978 & 5.12 & 5.16 & 0.14 & n.s. \\
\hline \multicolumn{5}{|c|}{ Milk fat yield (kg/day) } \\
\hline spring 1977 & 0.68 & 0.66 & 0.03 & n.s. \\
\hline Spring 1978 & 0.55 & 0.55 & 0.02 & $n . s$. \\
\hline \multicolumn{5}{|c|}{ Milk protein content $(\%)$} \\
\hline Spring 1977 & 3.66 & 3.93 & 0.11 & n.s. \\
\hline Spring 1978 & 3.71 & 3.75 & 0.08 & n.s. \\
\hline \multicolumn{5}{|c|}{ Milk protein yield (kg/day) } \\
\hline Spring 1977 & 0.51 & 0.54 & 0.02 & n.s. \\
\hline Spring 1978 & 0.40 & 0.40 & 0.02 & n.s. \\
\hline
\end{tabular}

n.s. $P>0.05$ 
There were no differences observed between the two cultivars. The organic matter digestibilities of the cultivars in each year are shown in Table 6.

TABLE 6: MEAN IN VITRO ORGANIC MATTER DIGESTIBILITIES OF TWO ANNUAL RYEGRASS CULTIVARS

\begin{tabular}{|c|c|c|}
\hline & \multicolumn{2}{|c|}{ In vitro $D O M D^{*}$} \\
\hline & Tama & $G 4709$ \\
\hline Spring 1977 & 73.0 & 73.4 \\
\hline Spring 1978 & 81.3 & 72.1 \\
\hline
\end{tabular}

* Digestible organic matter as percentage of dry matter.

\section{DISCUSSION}

\section{Perennial Ryegrass Comparisons}

The lack of any consistent differences in the yield or composition of the milk from cows grazing Nui, Ruanui or G4708 ryegrasses, throughout lactation, indicates little difference in the voluntary intake of nutrients, when fed to appetite. The increases in milk fat and protein contents by cows grazing G4708 compared with Ruanui in the autumn were not expected. They cannot be explained by the slightly lower digestibility of the G4708, and Wilson (1967) showed that cows grazing another tetraploid cultivar (Tama) in June had significantly lower milk fat and solids-not-fat contents than cows grazing Ruanui. The increased yield of protein in the spring of 1978 'from cows grazing Ruanui compared with G4708 amounted to only $20 \mathrm{~g} / \mathrm{cow} /$ day and was not observed in any of the other grazing trials.

This similarity in production and composition of milk from cows grazing these cultivars implies that the decision regarding their use in mixed pastures for dairying can be made upon differences in potential yield and seasonal distribution of growth rather than differences in feed quality. Nui generally outyields Ruanui in many parts of the country, particularly in autumn and winter (Lancashire et al., 1979), and G4708 appears more persistent but less winter-active, particularly in the first year, than Manawa. Wilson and McDowall (1966) observed higher milk yields from cows grazing Manawa compared with those grazing Ariki or Ruanui. Sheep grazing trials have shown little difference in feeding value between G4708 and Ariki (Lancashire and Ulyatt, 1975 ), and thus it would appear that the animal production characteristics of G4708 resemble Ariki rather than Manawa. 


\section{Annual Ryegrass COMPaRisons}

The results indicate that G4709 more closely resembles Tama in feeding value than it does Paroa. Wilson (1967) found greater yields of milk fat from cows grazing Paroa in winter compared with Tama, although these differences were less in spring. The nutritional advantage of Paroa, however, may be offset by the greater herbage yield of G4709 in winter and early spring (Lancashire, 1978). This greater yield and persistency of G4709 may lead to its replacing Paroa in 1- to 2-year pastures, although the even greater yield of Tama (Lancashire, 1978) will ensure its continued use in very short-term (6- to g-month) pastures if correct agronomic procedures are used (Scott and Brown, 1979).

\section{ACKNOWLEDGEMENTS}

To A. C. Lowe, G. J. Fowles and B. L. Baggot for the management of cows and pastures, and J. A. Raven for collection and analysis of milk and pasture samples.

\section{REFERENCES}

Armstrong, C. S., 1977. N.Z. $/ l$ exp. Agric., 5: 381-4.

Lancashire, J. A., 1978. Proc. Agron. Soc. N.Z.. 8: 123-7.

Lancashire, J. A.; Harris, A. J., 1978. Proc. N.Z. GrassId Ass., 39: 108-20.

Lancashire, J. A.; Harris, A. J.; Armstrong, C. S.; Ryan, D. L.. 1979. Ibid., 40: 114-24.

Lancashire, J. A.; Ulyatt, M. J., 1975. N.Z. JI agric. R es., 18: 97-100.

Scott, W. R.; Brown, K. R., 1979. Proc. N.Z. Grassld A ss., 40: 180-3.

Snedecor, G. W.; Cochran, W. C., 1967. Statistical M ethods (6th edit.). Iowa State University Press, Ames, Iowa, U.S.A.

Tilley, J. M. A.; Terry, R. A., 1963. J. Br. Grassld Soc., 18: 104-11.

Ulyatt, M. J., 1970. Proc. N.Z. Grassld Ass., 32: 61-8.

Wilson, G. F., 1967. Proc: N.Z. Grassld A ss., 29: 102-10.

Wilson, G. F.; Dolby, R. M., 1967. N.Z. Il agric. R es., 10:412-24.

Wilson, G. F.; McDowall, F. H., 1966. I bid., 9: 1042-52. 